\title{
ASSEMBLAGES OF BIRD AND MAMMAL COMMUNITIES IN TWO MAJOR ECOLOGICAL UNITS OF THE ANDEAN HIGHLAND PLATEAU OF SOUTHERN PERU
}

\section{ESTRUCTURA DE LAS COMUNIDADES DE AVES Y MAMÍFEROS EN DOS UNIDADES ECOLÓGICAS DE LOS ANDES DEL SUR DEL PERÚ}

\author{
Oswaldo Ramirez ${ }^{1}$, Margarita Arana ${ }^{1}$, Enrique Bazán ${ }^{1}$, Angel Ramirez ${ }^{2}$ y Asunción Cano²
}

\begin{abstract}
Grasslands in the Andean highlands plateau of southern Peru have been considered as a single and homogeneous dry habitat also known as Puna. However, in some regions, a highest rainfall regimen is found, and the name of wet puna has begun to be used by some authors. Since no studies have been carrying out specifically to test if dry and wet puna are different ecological units, we chose two representative localities of each one of these habitat to evaluate assemblages of bird and mammal communities and their continuity or independence between these apparently similar habitats. Our results suggest that wet puna has different mammal diversity than dry puna, and a heterogeneous bird community with species that have been previously reported exclusively in paramo or exclusively in puna. In spite of the apparent uniform flora in the Andean highlands of South Peru, data suggest that rainfall regimens produce a mosaic of habitats that will be determining ecological barriers for terrestrial mammals, in particular for small mammals.
\end{abstract}

Key words: Andean grasslands, Andean plateau, Cuzco, Oriental Cordillera, paramo, puna, Puno.

\section{Resumen}

Los Pajonales de los Andes del sur del Perú, también conocidos como Puna, son considerados como hábitats homogéneos y secos. Sin embargo, en algunas regiones se encuentra un alto régimen de precipitaciones y algunos autores han empezado a usar el nombre de Puna Húmeda. Hasta la actualidad no se vienen realizando estudios específicos para probar si la Puna Húmeda y Seca son dos unidades ecológicas diferentes. Se escogieron dos localidades representativas de cada uno de estos hábitat para evaluar la estructura de las comunidades de aves y mamíferos y su continuidad o independencia entre estos hábitat aparentemente similares. Los resultados sugieren que la Puna Húmeda tiene una diversidad de mamíferos diferente a la de la Puna Seca, y una comunidad de aves heterogénea con especies que vienen siendo previamente reportadas como exclusivas de Páramo o de Puna. A pesar de la aparente uniformidad de la flora en los Andes del sur del Perú, la información sugiere que los regimenes de precipitaciones producen un mosaico de hábitat que estaría determinando barreras ecológicas para mamíferos terrestres, en particular para pequeños mamíferos.

Palabras claves: Pajonal, Andes, Cuzco, Cordillera Oriental, Páramo, Puna, Puno

\section{Introduction}

Two major ecological units have been distinguished in the Andean Highlands above 3300 m. In most of Peru and southward this altitudinal zone is known as "Puna" (Reig, 1986; Young et al., 1997), whereas from Colombia and western Venezuela through most of Colombia and Ecuador up to northern Peru as "paramo" (Cuatrecasas, 1957; Vuilleumier, 1979). However, floristic boundaries have not been rigorously established to delimit unambiguously these ecological units.

In general the Peruvian puna is relatively dry (Young et al., 1997), but wetter areas in northern Peru are distinguished by the term "jalca" (Weberbauer, 1945), and in southern Peru as wet Puna (Tossi, 1960; Troll, 1968).
Grassland, also known as Puna by some authors, is the predominant vegetation type in the Andean highlands, although woodland patches, scrub and wetlands are also frequently found.

Only relatively small areas of Puna are included within protected areas in southern Peru. For example, only 1.4 percent of the Manu National Park (Departments of Madre de Dios and Cuzco, Peru), one of the largest protected areas in the world, is representative of the Andean highlands (Plan Maestro del Parque Nacional del Manu, 2004). Two other protected areas that include highlands in the Southern Peru are Salinas y Aguada Blanca National Reserve, and Aymara-Lupaca Reserved Zone.

In this work, we carried out a diversity evaluation of birds and mammals in two Andean highland localities of South Peru. One of them, a wet Puna site 
in Acjanaco, Eastern Andes, is located within Manu National Park, while the other locality is a dry Puna site in Tupala, located in the highland plateau of the Aymara-Lupaca Reserved Zone.

Our principal aim for this study was not to obtain complete biological inventories, but to study the assemblage of bird and mammal communities in representative areas of the grasslands, scrub and upper montane forest of the Andean highlands of southern Peru. Data on species assemblage and biodiversity in these selected habitats will provide a better insight into the biotic and biogeographical relationships between these regions.

\section{Methods}

STUDY AREA.- Tupala is a very small town of pastoralists in the highland plateau of the Department of Puno, Peru (1700'42'’S, 69³7'52'’W, 4000 m elevation). This locality is a typical dry Puna with less than $400 \mathrm{~mm}$ of annual precipitation, falling usually between December and April. Nearby Tupala, two habitat were studied: the scrub locally known as tola and the alpine grassland or "pajonal". Tola is the Andean equivalent of sagebrush and consists of flat expanses of bushes of one or more species of Lepidophyllum or Bacharis (Asteraceae) (Pearson \& Ralph, 1978). In the tola habitat of Tupala the dominant shrubs were Parastrephia lucida, Baccharis incarum, Senecio spinosus and Adesmia espinosa. Meanwhile, in the grassland habitat of Tupala, two families were dominant: Poaceae (species of genus Stipa, Calamagrostis, and Muhlenbergia) and Rosaceae (Alchemilla pinnata).

Acjanaco is a locality on the eastern flanks of the Eastern Cordillera of South Peru, in the Department of Cuzco (1311'47's, 71'37'10'’ W, $3450 \mathrm{~m}$ ). The mean annual precipitation is between 1000 and 2000 $\mathrm{mm}$, and the mean annual temperatures are around 6$10^{\circ} \mathrm{C}$ (Cano et al., 1995). This locality is a wet Puna where two absolutely different habitats converge, the upper montane rain forest and the tropical alpine grassland. The upper montane forest has a high diversity of flowering plants in comparison to the grassland habitat of Acjanaco (Cano, 1994).

The flora of the upper montane forest in Acjanaco is dominated by trees of Polylepis and Clethra, and shrubs of Oreopanax and Gynoxis. In the grassland habitat, the most abundant genus are Calamagrostis, Cortaderia, Stipa (Poaceae), Gaultheria and Pernettya (Ericaceae) (Young \& Cano, 1994).

A total of four habitats were studied: tola and grassland in Tupala, and upper montane forest and grassland in Acjanaco. Grasslands of these localities are representative of the wet and dry puna of the southeastern highland plateau of Peru.

Fieldwork was conducted in each study area once during the dry season (Acjanaco: between 28 August 2004 and 10 September 2004; Tupala: between 26
September 2004 and 7 October 2004) and once in the wet season (Acjanaco: between 17 March 2004 and 29 March 2004; Tupala: between 3 March 2004 and 15 March 2004).

BIRDS.- A list of birds was prepared considering all species seen in the study areas. Between four and eleven observation stations (depending on the visual amplitude of each habitat) were established in appropriate places to avoid disturbance of normal bird activities. Observation stations were visited every day at different times, each visit lasting 20 minutes, and in which all birds seen or heard were recorded. Additional data were obtained during walking between stations to ensure that all possible species were listed and compiled for each site. Observations were conducted from $0630 \mathrm{~h}$ to $1030 \mathrm{~h}$ and from 1400 $\mathrm{h}$ to $1800 \mathrm{~h}$ when climate conditions allowed. Mist nets were used to capture birds along the smallmammal trapping lines to recognize the assemblage of bird and mammal communities in specific habitats. Birds were identified using Koepcke (1970), Fjeldsa \& Krabbe (1990) and Clements \& Shany (2001). Bird voucher specimens were compared with specimens deposited in the Museo de Historia Natural of Universidad Nacional Mayor de San Marcos for taxonomic identifications.

MAMMALS.- Small mammals were surveyed by trapping along two 200-m long trails in each site. Trap stations were located at $10-\mathrm{m}$ intervals along each trail, and consisted of one Sherman live trap or one Victor rat trap in alternate order. Trapping was carried out for 10 consecutive days on each trail. Traps were baited with peanut butter mixed with rolled oats. Trap stations along two trails were monitored simultaneously. Additional trapping in microhabitats that were not represented in the main study areas was implemented to increase the probability of collecting uncommon species that might occur in the study areas. Large and medium mammals were recorded by sightings or identifiable tracks.

\section{Results}

BIRDS OF TUPALA.- Bird richness in the tola vegetation was higher than in the grassland habitat. Eleven bird species representing eight families were recorded in the grasslands, compared to the 25 bird species and 10 families associated with the tola habitat (Table 1; Table 5). Nine bird species were common to both. Another 18 bird species were observed in places near the study area. A total of 45 birds species were recorded near Tupala. In the tola habitat, Furnariidae was the family with more species (7 species), followed by Emberezidae (4 species), Tyrannidae and Fringillidae with three species each (Tables 1, 5, 6). In the grassland habitat all families were represented by 1 or 2 species. Two species, Tinamotis pentlandii and Muscisaxicola alpine, were observed exclusively in grassland areas, all other grassland species were also 
recorded in the tola habitat (Table 1). Sixteen bird species were observed in the tola habitat but were not present in the grassland habitat (Table 5). Phrygilus plebejus was the most commonly observed bird species in both tola and grassland habitats.

Table 1. Bird species diversity in the grassland (G)

\begin{tabular}{|c|c|c|c|}
\hline Order & Family & Species & $\begin{array}{l}\text { Habi- } \\
\text { tat }\end{array}$ \\
\hline \multirow[t]{3}{*}{ Tinamiformes } & Tinamidae & Nothoprocta ornata & GT \\
\hline & & Nothoprocta pentlandii & $\mathrm{T}$ \\
\hline & & Tinamotis pentlandii & G \\
\hline \multirow[t]{2}{*}{ Columbiforme } & Columbida & Metriopelia aymara & GT \\
\hline & Psittacidae & Bolborhynchus orbygnesius & $\mathrm{T}$ \\
\hline Apodiformes & Trochilidae & Oreotrochilus estella & $\mathrm{T}$ \\
\hline Piciformes & Picidae & Colaptes rupícola & GT \\
\hline \multirow[t]{20}{*}{ Passeriformes } & Furnariidae & Asthenes modesta modesta & GT \\
\hline & & Cinclodes atacamensis & $\mathrm{T}$ \\
\hline & & Cinclodes fuscus & $\mathrm{T}$ \\
\hline & & Geositta cunicularia & $\mathrm{T}$ \\
\hline & & Geositta tenuirostris & $\mathrm{T}$ \\
\hline & & Leptasthenura striata & $\mathrm{T}$ \\
\hline & & Upucerthia jelskii & GT \\
\hline & Tyrannidae & Muscisaxicola albifrons & $\mathrm{T}$ \\
\hline & & Muscisaxicola alpina & G \\
\hline & & Muscisaxicola juninensis & $\mathrm{T}$ \\
\hline & & Ochthoeca oenanthoides & $\mathrm{T}$ \\
\hline & Hirundinid & Stelgidopteryx andecola & GT \\
\hline & & Pygochelidon cyanoleuca & GT \\
\hline & Fringillidae & Carduelis atrata & $\mathrm{T}$ \\
\hline & & Carduelis crassirostris & $\mathrm{T}$ \\
\hline & & Carduelis uropygialis & GT \\
\hline & Emberezid & Phrygilus plebejus & GT \\
\hline & & Phrygilus punensis & $\mathrm{T}$ \\
\hline & & Sicalis olivascens & $\mathrm{T}$ \\
\hline & & Zonotrichia capensis & $\mathrm{T}$ \\
\hline
\end{tabular}

Five species were observed in wetlands and small rivers nearby Tupala, but not in grassland or tola habitats (Chloephaga melanoptera, Anas flavirostris, Anas specularioides, Vanellus resplendens and Larus serranus). Accipitridae species, Buteo poecilochrous, Buteo polyosoma, Circus cinereus, Geranoetus melanoleucus, and the Falconidae Falco femoralis and Phalcoboenus megalopterus were not included as grassland or tola bird species because they have long distance movements and could be seen over-flying the grassland or tola study area. Nearby Tupala and $100 \mathrm{~m}$ from the river, a pair of Lessonia oreas, one individual of Thinocorus orbignyanus and one Muscisaxicola rufivertex pallidiceps were observed. Some species were strongly associated with human activity. Two doves, Metriopelia ceciliae and Columba maculosa, were recorded only in Tupala town, as well as the finch Sicalis uropygialis. The sparrow Zonotrichia capensis and $S$. uropygialis which were abundant within the town, nesting under house roofs. Captive Rhea pennata breed near Tupala and local people have been able to see wild individuals in the higher mountains, away from human activity.

MAMMALS OF TUPALA.- Twelve species of mammals were recorded in Tupala (Tables 3, 5), including seven rodent species, three carnivorous, one artiodactyl and one lagomorph. Rodent species included Phyllotis xanthopygus, Auliscomys sublimis, Calomys lepidus, Bolomys amoenus, Chroeomys jelskii, Akodon boliviensis and Akodon albiventer. All these species belong to the Sigmodontinae subfamily (Muridae). Carnivores observed in the area were the Pseudalopex culpaeus (Andean fox; Canidae), Galictis cuja (lesser grison; Mustelidae) and Lynchailurus jacobita (pampas cat; Felidae). The artiodactyl mammal was Vicugna vicugna (vicugna; Camelidae), and the lagomorph was the introduced European rabbit, Oryctolagus cuniculus (Leporidae; Table 3).

In the tola habitat all seven rodent species were collected, but only $C$. lepidus, B. amoenus and $A$. boliviensis were found in the grassland area traps (Table 3, 6). The most commonly captured rodents in Tupala were $A$. boliviensis, $C$. lepidus and $B$. amoenus, while only four or fewer individuals of the other rodent species were captured during the fieldwork in both seasons.

BIRDS OF ACJANACO.- In Acjanaco, four bird species were recorded in the grasslands, and 41 species in the upper montane forest (Tables 2, 5). None of the bird species was common to both types of habitat. Another 11 species were observed in other places near the study area. A total of 56 birds species were recorded in all areas around Acjanaco (Table 5).

In the upper montane forest habitat, 16 families were recorded. Thraupidae was the family with the highest number of species (8 species), followed by Trochilidae (7 species), Tyrannidae (6 species), Emberezidae (4 species) and Furnariidae (3 species; Table 2, 6). Diglossa mystacalis albilinea and Anisognathus igniventris were the most common species in the upper montane forest, and they were frequently observed forming mixed flocks with Iridisornis jelskii and Diglossopis cyanea in open areas of the forest, with predominance of bushes. Other species joined in flocks at the upper montane forest were Cacicus chrysonotus chrysonothus and Buthraupis montana. An endemic Acjanaco species, Schizoeaca helleri, was recorded in this habitat. 
Diciembre 2007

Table 2. Bird species diversity in the grassland (G) and upper montain forest (F) habitats of Acjanaco.

\begin{tabular}{|c|c|c|c|}
\hline Order & Family & Species & $\begin{array}{l}\text { Habi- } \\
\text { tat }\end{array}$ \\
\hline Galliforme & Cracidae & Penelope montagnii & $\mathrm{F}$ \\
\hline Psittacifor & Psittacidae & Bolborhynchus orbygnesius & $\mathrm{F}$ \\
\hline \multirow[t]{7}{*}{ Apodiform } & Trochilidae & Coeligena torquita & $\mathrm{F}$ \\
\hline & & Coeligena violifer osculans & $\mathrm{F}$ \\
\hline & & Colibri coruscans & $\mathrm{F}$ \\
\hline & & Ensifera ensifera & $\mathrm{F}$ \\
\hline & & Heliangelus amethysticollis & $\mathrm{F}$ \\
\hline & & Metallura tyrianthina & $\mathrm{F}$ \\
\hline & & Pterophanes cyanopterus & $\mathrm{F}$ \\
\hline Trogonifor & Trogonidae & Trogon personatus & $\mathrm{F}$ \\
\hline Piciformes & Picidae & Veniliornis nigriceps & $\mathrm{F}$ \\
\hline \multirow[t]{34}{*}{ Passerifor } & Furnariidae & Margarornis squamiger & $\mathrm{F}$ \\
\hline & & Pseudocolaptes boissonneautii & $\mathrm{F}$ \\
\hline & & Schizoeaca helleri & $\mathrm{F}$ \\
\hline & Dendrocolapti & Dendrocincla tiranía & $\mathrm{F}$ \\
\hline & Formicariidae & Grallaria rufula occabambae & F \\
\hline & & Grallaria squamigera & $\mathrm{F}$ \\
\hline & Phytotomidae & Pipreola arcuata & $\mathrm{F}$ \\
\hline & Tyrannidae & Muscisaxicola alpina & $\mathrm{F}$ \\
\hline & & Myiotheretes fumigatus & F \\
\hline & & Ochthoeca oenanthoides & $\mathrm{F}$ \\
\hline & & Ochthoeca fumicolor berlepschi & $\mathrm{F}$ \\
\hline & & Ochthoeca rufipectoralis & $\mathrm{F}$ \\
\hline & & Ochthoeca spodionota & $\mathrm{F}$ \\
\hline & Hirundinidae & Pygochelidon cyanoleuca & G \\
\hline & Troglodytidae & Cistothorus platenses & G \\
\hline & & Troglodytes aedon & G \\
\hline & Turdidae & Turdus chiguanco & $\mathrm{F}$ \\
\hline & & Turdus fuscaster ockenderi & $\mathrm{F}$ \\
\hline & Corvidae & Cyanolyca viridicyana & $\mathrm{F}$ \\
\hline & Parulidae & Basileuterus luteoviridis & $\mathrm{F}$ \\
\hline & Thraupidae & Anisognathus igniventris & $\mathrm{F}$ \\
\hline & & Buthraupis montana & $\mathrm{F}$ \\
\hline & & Conirostrum ferrugineiventre & $\mathrm{F}$ \\
\hline & & Chlorornis riefferii & $\mathrm{F}$ \\
\hline & & Delothraupis castaneoventris & $\mathrm{F}$ \\
\hline & & Hemispingus trifasciatus & $\mathrm{F}$ \\
\hline & & Iridosornis jelskii & $\mathrm{F}$ \\
\hline & & Thlypopsis ruficeps & $\mathrm{F}$ \\
\hline & Emberezidae & Diglossa brunneiventris & $\mathrm{F}$ \\
\hline & & Diglossa mystacalis albilinea & $\mathrm{F}$ \\
\hline & & Diglossa sittoides & $\mathrm{F}$ \\
\hline & & Diglossopis cyanea & $\mathrm{F}$ \\
\hline & & Zonotrichia capensis & G \\
\hline & Icteridae & Cacicus chrysonothus & $\mathrm{F}$ \\
\hline
\end{tabular}

Table 3. Mammal species diversity in the grassland (G) and tola (T) habitats of Tupala.

\begin{tabular}{llll}
\hline Order & Family & \multicolumn{1}{c}{ Species } & Habitat \\
\hline Carnivora & Canidae & $\begin{array}{l}\text { Pseudalopex } \\
\text { culpaeus } \\
\text { Lynchailurus } \\
\text { jacobita }\end{array}$ & GT \\
& Felidae & GT \\
Artiodactyla & Mustelidae & $\begin{array}{l}\text { Galictis cuja } \\
\text { Rodentia }\end{array}$ & GT \\
& Muridae & $\begin{array}{l}\text { Vicugna vicugna } \\
\text { Akodon albiventer } \\
\text { Akodon boliviensis }\end{array}$ & GT \\
& & GT \\
& & $\begin{array}{l}\text { Auliscomys sublimis } \\
\text { Bolomys amoenus } \\
\text { Calomys lepidus }\end{array}$ & T \\
& & GT \\
& & $\begin{array}{l}\text { Chroeomys jelskii } \\
\text { Phyllotis }\end{array}$ & T \\
xanthopygus & T \\
Oryctolagus & GT \\
\hline Lagiculus & & \\
\hline
\end{tabular}

Table 4. Mammal species diversity in the grassland (G) and upper mountain forest (F) habitats of Acjanaco.

\begin{tabular}{|c|c|c|c|}
\hline Order & Family & Species & Habitat \\
\hline Paucituberculata & Caenolestidae & Lestoros inca & $\mathrm{F}$ \\
\hline \multirow[t]{2}{*}{ Carnivora } & Canidae & $\begin{array}{l}\text { Pseudalopex } \\
\text { culpaeus }\end{array}$ & G \\
\hline & Mustelidae & Mustela frenata & FG \\
\hline Artiodactyla & Cervidae & $\begin{array}{l}\text { Odocoileus } \\
\text { virginianus }\end{array}$ & FG \\
\hline \multirow[t]{6}{*}{ Rodentia } & Muridae & Akodon torques & FG \\
\hline & & Akodon subfuscus & G \\
\hline & & $\begin{array}{l}\text { Microryzomys } \\
\text { minutus }\end{array}$ & G \\
\hline & & $\begin{array}{l}\text { Thomasomys } \\
\text { daphne }\end{array}$ & $\mathrm{F}$ \\
\hline & & Thomasomys sp. 1 & $\mathrm{~F}$ \\
\hline & Cavidae & Cavia tschudii & G \\
\hline
\end{tabular}

In the grassland study area only three families were recorded: Troglodytidae, represented by two species, and Hirundinidae and Emberezidae, represented by only one species each. The two wrens, Cistothorus platensis and Troglodytes aedon, were the most common bird species recorded in the grasslands. The swallow Pygochelidon cyanoleuca was observed nearby and overflying small water bodies.

The falconiformes Phalcoboenus megalopterus, Buteo polyosoma and Circus cinereus were commonly seen overflying the grassland areas of Acjanaco. A swift, Streptoprocne zonaris, was seen too. Although these birds were seen in the open grasslands, they were not included as birds related to this type of habitat due to their long distance movements. 
Table 5. Birds and mammals species number in habitats of Dry and Wet Puna.

\begin{tabular}{|c|c|c|c|c|c|}
\hline \multicolumn{3}{|c|}{ Dry Puna ( Tupala ) } & \multicolumn{3}{|c|}{ Wet Puna ( Acjanaco ) } \\
\hline Habitat & $\begin{array}{c}\text { Birds } \\
\text { (n) }\end{array}$ & $\begin{array}{l}\text { Mammals } \\
\text { (n) }\end{array}$ & Habitat & $\begin{array}{c}\text { Birds } \\
\text { (n) }\end{array}$ & $\begin{array}{l}\text { Mammals } \\
\text { (n) }\end{array}$ \\
\hline Tola only & 16 & 4 & $\begin{array}{l}\text { Upper mountain } \\
\text { forest only }\end{array}$ & 41 & 3 \\
\hline Grassland only & 2 & 0 & Grassland only & 4 & 4 \\
\hline $\begin{array}{l}\text { Tola and } \\
\text { Grassland }\end{array}$ & 9 & 8 & $\begin{array}{l}\text { Upper mountain } \\
\text { forest and } \\
\text { Grassland }\end{array}$ & 0 & 3 \\
\hline Others & 18 & 0 & Others & 11 & 0 \\
\hline Total & 45 & 12 & Total & 56 & 10 \\
\hline
\end{tabular}

Table 6. Birds and mammals families in habitats of Dry and Wet Puna.

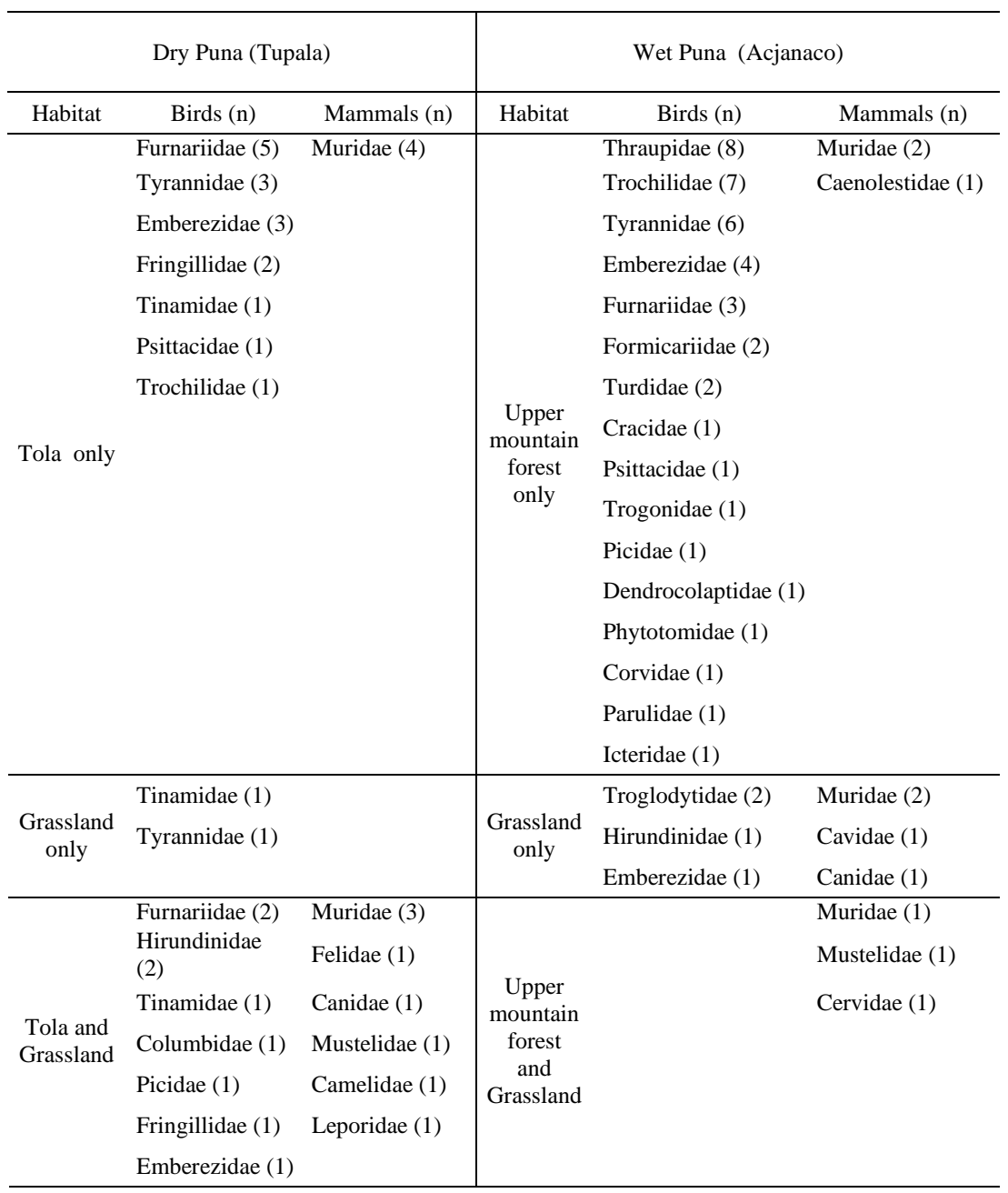

$\mathrm{n}=$ species number

A line of Polylepis trees, planted by guard parks several decades ago, flanked the borders of a road that cross grassland areas in Acjanaco. We frequently observed the Tyrannidae Ochthoeca oenanthoides polionota and Ochthoeca fumicolor berlepschi flying along these trees. Eventually, other bird species such as the thrushes Turdus chiguanco and Turdus fuscaster ockenderi, and the Emberezidae Zonotrichia capensis and Sicalis olivascens were observed in these Polylepis trees.

We recorded other species such as the Caprimulgidae Uropsalis segmentata, the Furnariidae Cinclodes atacamensis and C. fuscus, the Thraupidae Thraupis bonariensis, and Emberezidae such as Catamenia inornata and Phrygilus plebejus, living around the guard park house. In addition, we also observed at this place some species recorded in grasslands and upper montane forest such as the wren Troglodytes aedon, the flowerpiercer Diglossa mystacalis albilinea, the Andean guan Penelope montagnii, the chat-tyrants Ochthoeca oenanthoides polionota and Ochthoeca fumicolor berlepschi, the thrushes Turdus chiguanco and Turdus fuscaster ockenderi and the rufouscollared sparrow Zonotrichia capensis. MAMMALS OF ACJANACO.- Ten species of mammals were recorded in Acjanaco (Tables 4, 5), including one marsupial, six rodents, two carnivorous and one artiodactyl. The marsupial collected was Lestoros inca (Paucituberculata, Caenolestidae), the rodent species included Thomasomys sp. 1 (Pacheco, 2003), Thomasomys daphne, Microryzomys minutus, Akodon subfuscus and Akodon torques, all of them belonging to the Sigmodontinae subfamily (Muridae), and a Cavidae (Cavia tschudii). Carnivorous observed in the area include the Andean fox (Pseudalopex 
culpaeus; Canidae) and the long-tailed weasel (Mustela frenata; Mustelidae). The only Artiodactyla seen in this area was the white-tailed deer (Odocoileus virginianus; Cervidae; Table 4).

In the upper montane forest we collected the small mammal species Lestoros inca, Thomasomys sp. 1 (Pacheco, 2003), T. daphne and Akodon torques, but in the grassland habitat we collected Microryzomys minutus, Akodon torques, A. subfuscus and Cavia tschudii. The Andean fox was observed in the grassland area, while the white-tailed deer was observed in the ecotone area between upper montane forest-grassland and grasslands. The long-tailed weasel was observed in both types of habitat (Tables $4,6)$.

The most commonly captured rodent in Acjanaco was A. torques. Only two individuals of Lestoros, three of Thomasomys and two of Microryzomys were collected during the complete study. Cavia population size was higher during the wet season than during the dry season.

\section{Discussion and conclusions}

BIRDS.- A total of 56 bird species were recorded in Acjanaco (Cosñipata drainage), 10 of which constitute new records for this locality, increasing their bird richness to 113 species, five of them are new records for the Manu Biosphera Reserve (MBR). Recently, Walker et al. (2006) listed 104 species for Acjanaco and 1005 species for MBR (Patterson et al., 2006). The five new records for MBR, Muscisaxicola alpina, Ochthoeca spodionota, Sicalis olivascens, Cinclodes atacamensis and Phrygilus plebejus, more Bolborhynchus orbygnesius, Circus cinereus, Coeligena torquata, Cyanolyca viridicyanus and Myiotheretes fumigatus constitute the 10 new records for Acjanaco.

In the upper montane forest of Acjanaco, many bird species were conspicuous for their colorful plumage, mainly tanagers and hummingbirds, meanwhile birds in the other three study areas were less colourful. Among hummingbirds, two species drew our attention: Ensifera ensifera, with its amazingly long bill, and Pterophanes cyanopterus for its large body size. The upper montane forest of Acjanaco is the only locality where Schizoeaca helleri has been recorded.

Our list of 45 bird species for Tupala constitutes the first bird inventory for this locality. Within this group, 23 species were shared with Acjanaco and the other 22 were recorded only in Tupala. Common species recorded by us and previous studies in both Tupala and Acjanaco are: Nothoprocta pentlandii, $N$. ornata, Anas specularioides, A. flavirostris, Chloephaga melanoptera, Buteo poecilochrous, $B$. polyosoma, Circus cinereus, Geranoetus melanoleucus, Phalcoboenus megalopterus, Vanellus resplendens, Larus serranus, Bolborhynchus orbygnesius, Colaptes rupicola, Cinclodes atacamensis, C. fuscus, Muscisaxicola alpina, Ochthtoeca oenanthoides, Pygochelidon cyanoleuca, Phrygilus plebejus, P. punensis, Sicalis olivascens and Zonotrichia capensis. If we considered only the bird species recorded in this study, the number of shared species would be reduced to 12 .

Since the principal aim of our study was not to produce a complete inventory of species, we did not expect to record all species in each locality. However, 10 new records for Acjanaco in our relatively small study areas suggest to us that a complete species list is still a future task. The number of bird species recorded in the upper montane forest of Acjanaco (41 species, 16 families; Tables 2, 5 and 6) indicates that this specific region is by far the richest of all the localities monitored in this study, followed by the tola habitat of Tupala with 25 bird species and 10 families (Table 1, 5 and 6). This is an expected result because it is known that there is a positive relationship between bird species diversity and measures of habitat structure (MacArthur et al., 1966).

In the grassland areas studied here, we recorded 11 bird species (8 families) in Tupala and only four species (3 families) in Acjanaco. In Tupala, nine species were common to grassland and tola habitats. On the other hand, between the Acjanaco grassland and upper montane forest areas no bird species were shared, suggesting that these species have a major specialization for their habitats (Table 5).

MAMMALS.- A similar richness in mammal species was found in the localities of Tupala and Acjanaco (Table 5). However, a differently structured community was observed in these areas, without common species with exception of the Andean fox Pseudalopex culpaeus. Three mammal genera common to both localities were the fox Pseudalopex, and the rodents Akodon and Phyllotis. Seven and nine mammal genera were exclusively found in Acjanaco and Tupala, respectively.

A list of terrestrial mammals nearby to Acjanaco can be obtained from Pacheco et al. (1993), joining all species recorded in four localities between 3200 and 3 $500 \mathrm{~m}$ of altitude (Acjanaco, Trocha Ericsson, Macho Cruz and Tres Cruces). Three of these localities, except Tres Cruces, were partially evaluated in the present study and included in only one locality (Acjanaco) for us. The list based in Pacheco et al. (1993) includes 21 species of terrestrial mammals. A more recently list for terrestrial mammals of this region can be extracted from Solari et al. (2006). This new checklist include to Oligoryzomys andinus and take into account than Thomasomys sp. 9 (Pacheco, 2003) and a specimen from Tres Cruces previously listed as T. gracilis by Pacheco et al. (1993) are synonymous. Thus, the total number of terrestrial mammals of Acjanaco remains without changes (21 species). 
The species that were not recorded in our study but reported by Pacheco et al. (1993) were: Tremarctos ornatus, Conepatus chinga, Puma concolor, Mazama chunyi, Oligoryzomys sp., Oxymycterus paramensis, Phyllotis osilae, Thomasomys sp. 9 and Cuniculus taczanowskii.

In Acjanaco, rodents of the genus Thomasomys and the paucituberculate genus Lestoros occur only in the montane forest, whereas Cavia tschudii and Oxymycterus paramensis have been found only in the grassland habitat (Pacheco et al., 1993; Solari, 1997). Cavia tschudii has a large distributional area in Peru and north of Chile and Bolivia, always associated with grasslands (Spotorno et al., 2004). Thomasomys is the most diverse rodent genus in Peru, with 19 species (Pacheco, 2002), and its large geographical range includes paramo and montane forest habitats. All of these species seem more specialized for their corresponding habitats.

Although Akodon torques was frequently captured in the montane forest and $A$. subfuscus in the grasslands, our records and previous studies in Acjanaco have shown that $A$. torques can be found in both habitats (Pacheco et al., 1993; Solari, 1997; Solari et al., 2006), suggesting a more generalist ecological behaviour. In Peru, A. subfuscus occurs from the moist puna grassland on the eastern Andean slope above $3200 \mathrm{~m}$ in the Departments of Puno and Cusco, through the bunchgrass, tola shrub, and cactus scrub habitats in the Departments of Apurimac, Arequipa and Ayacucho (Myers et al., 1990; Patton \& Smith, 1992). Akodon torques is an inhabitant of the upper elfin forest on the eastern slope of the Andes in the Departments of Ayacucho and Cusco, between 2 000 and $3500 \mathrm{~m}$ (Patton \& Smith, 1992). The taxonomy of $A$. torques requires a revision, its populations show a wide range of diploid numbers from 26 in the Department of Ayacucho to 22 in the Urubamba drainage in the Department of Cusco (Patton \& Smith, 1992), suggesting that a complex of species could be present in this taxon. We found Microryzomys minutus in disturbed grasslands near the guard park house, but this species was also collected by Pacheco et al. (1993) in several montane forest localities of the Cosñipata Valley, between 2450 and $3400 \mathrm{~m}$. The long-tailed weasel Mustela frenata was recorded in montane forest and grassland habitats. The white-tailed deer Odocoileus virginianus was recorded in the ecotone between montane forestgrassland and grasslands, and the Andean fox Pseudalopex culpaeus was only observed in the grasslands. In a previous study (Pacheco et al., 1993), $M$. frenata was recorded only in the montane forest, meanwhile $O$. virginianus was observed only in the grassland habitat. Thus, our records suggest that $M$. frenata and $O$. virginianus occur in more vast diversity of habitats than previously reported for Acjanaco. Lestoros inca is a poorly-known marsupial that has been recorded in the montane forest of Cosñipata Valley between 2100 and $3400 \mathrm{~m}$ (Pacheco et al., 1993), and two other similar localities: Machu Picchu Sanctuary (Solari et al., 2001) and northern Bolivia (Anderson, 1997).

This is the first study on the mammal diversity of Tupala, so no comparisons with previous studies are possible. One striking observation is that no small mammals and only one medium-size mammal, the Andean fox, was shared with the Acjanaco mammal community, in spite of the apparent connectivity among grassland habitats in the highland plateau. Several mammal species found in Tupala have large distribution ranges such as the rodent species Phyllotis xanthopygus and Chroeomys jelskii, as well as the artiodactyl Vicugna vicugna, but they did not occur in Acjanaco, suggesting that ecological more than historical factors are involved in these different communities.

ANDEAN HIGHLAND BIOGEOGRAPHY.- Some decades ago, Tossi (1960) and Troll (1968) distinguished between wet puna (above $400 \mathrm{~mm}$ ) and dry puna (100-400 mm) ecosystems based on the annual average precipitation, in spite of the apparent uniform flora in the Andean highlands of South Peru (Molina \& Little, 1981). Years later, Pacheco \& Patton (1995) recognized a biogeographical rodent subdivision in the southern Andes based on the species and subspecies levels of rodents on both sides of the Lake Titicaca Basin. In the dry, mountainous zones to the south of Lake Titicaca, the following rodent species have been recorded: Phyllotis osilae osilae, Auliscomys boliviensis, Punomys lemminus, Akodon andinus, A. berlepschii, A. boliviensis, A. subfuscus arequipae, Bolomys amoenus, Chroeomys jelskii pulcherrimus and Galea musteloides. On the other hand, the wetter puna of the Oriental Cordillera contains an assemblage of rodents consisting of Phyllotis osilae phaeus, Punomys kofordi, and Chroeomys jelskii cruceri and inambarii, as well as other species with wider distributions that do not occur in the Occidental Cordillera, such as Auliscomys pictus, Oxymycterus paramensis, Akodon puer, A. subfuscus subfuscus and Oligoryzomys sp. B (Pacheco \& Patton, 1995). The different assemblages of mammal species between Acjanaco (wet puna) and Tupala (dry puna) recorded in this study not only confirms the biogeographical distinctness between wet puna and dry puna, but shows a more drastic separation between fauna assemblages, without rodent species shared between them. Besides, our results support the idea that the dry puna of the Occidental Cordillera appears to contain a larger assemblage of rodents than the wet puna (Pacheco \& Patton, 1995). Moreover, if only grassland and shrub habitats were considered (common habitats for both localities), seven and four rodent species would be present in Tupala and Acjanaco, respectively. But, as noted by 
Pacheco \& Patton (1995), the sampling efforts in both types of puna have been rather minimal.

Reig (1986) showed the lack of resemblance in species composition between the puna and paramo rodent faunas in the species, genera and supragenera levels, with a single shared species, Microryzomys minutus. The puna rodent fauna could be characterized as a phyllotine-caviomorph-akodontine assemblage, as 95 percent of the puna species belong to one of those taxa, while the paramo rodent fauna is mostly an oryzomyine fauna, with members of this tribe representing 59.2 percent of the total species number (Reig, 1986). The Acjanaco rodent community is strikingly similar to the paramo rodent fauna described by Reig (1986). Four of thirteen rodent species that occur in Acjanaco are included in the paramo rodent list proposed by Reig (1986), an unexpected number considering that no common rodent species occur between Acjanaco and Tupala. The paramo bioma defined by Reig (1986), in agreement with Cuatrecasas (1957), Vuilleumier (1979) and Vuilleumier \& Simberloff (1980), is discontinuously distributed from northern Colombia and western Venezuela through most of Colombia and Ecuador up to northern Peru $\left(11^{\circ} \mathrm{N}\right.$ to $\left.8^{\circ} \mathrm{S}\right)$ above the timberline, usually above $3000 \mathrm{~m}$. The Thomasomys genus is very diverse in the paramo rodent fauna, with 10 species, compared to only one species included in the puna list proposed by Reig (1986). At least four species of Thomasomys have been recorded in Acjanaco (Pacheco et al., 1993), as expected for a paramo locality. The wet Puna of Acjanaco, excepting its latitudinal position $\left(13^{\circ} \mathrm{S}\right)$, could be included within the definition of paramo bioma proposed by Reig (1986), a "high Andean biotic community of cold, humid, sometimes boggy meadows characterized by open vegetation of tussocks of grasses, composites, and flowering herbs and bushes, but also including islands of woodland vegetation." This similarity suggests the hypothesis that, in the Oriental Cordillera of South Peru, the recognized wet Puna is a group of patches that have a nearby biogeographical relationship with the typical paramo ecosystem, which limit has been previously established close to $8^{\circ} \mathrm{S}$ in North Peru.

The distinction between the wet puna and the dry puna bird communities is not as clear as in the mammal communities. Two factors limit our analysis. First, only four bird species were recorded in the grasslands of Acjanaco (Pygochelidon cyanoleuca, Cistothorus platensis, Troglodytes aedon and Zonotrichia capensis), impeding a good biogeographical analysis (i.e. small number of species). Second, it has been previously reported that the avifaunas in paramo and puna areas have many species and even more genera in common. Over 55 percent of paramo species and over 85 percent of paramo genera are also found in the larger puna fauna
(Vuilleumier \& Simberloff, 1980). However, we discuss briefly the significance of our data to support the hypothesis of a major similarity between Acjanaco and paramo biodiversity than the expected with the dry puna, typical of South Peru.

Paramo and puna formations have a sharp geographic dichotomy. While the paramo environment is insular, the puna environment is continuous. In addition, the paramo habitat is generally wetter than the puna, being found in the northern Andes, where annual precipitation is heavier and less seasonal (Vuilleumier \& Simberloff 1980). However, Vuilleumier \& Simberloff (1980) noticed that several paramo localities such as the Andes of Mérida in Venezuela, Páramo del Ruiz in the central Andes of Colombia, Páramo del Cocuy in the Eastern Andes of Colombia and Chimborazo in Ecuador have a vegetation that can encompass physiognomic types found in the distant and much drier puna, in spite of differences in climatic conditions. Thus, physiognomically, one can find much diversity within the paramo formation, as one does it within the puna (Troll, 1959), and a clear distinction between both types of highland environment is not easily reached. Vuilleumier \& Simberloff (1980) showed a list of bird species for a total of 23 paramo and 17 puna localities. Following this list, we tested the presence or absence of each one of the bird species found in Acjanaco. The analysis for grassland bird species showed that Pygochelidon cyanoleuca occurred in only one puna site and none in paramo sites, Cistothorus platensis occurred in 11 paramo sites and none in puna sites, Troglodytes aedon did not occur in paramo sites but it was present in 5 puna sites, and Zonotrichia capensis was present in multiples localities in both habitats. Among montane forest species only six species were present in the list, two of them (Ochthoeca fumicolor and Turdus fuscater) were frequently found in paramo sites but not in puna sites. Other two species (Ochthoeca oenanthoides and Turdus chiguanco) were present in puna sites but not in paramo sites. Colibri coruscans is included in the list as puna species, found in only one site, while Muscisaxicola alpina was present in eight paramo sites and in four puna sites. These results show that the Acjanaco bird fauna contains some bird species that can be considered as representative of paramo fauna, but others that can be typical of dry puna, and that is difficult to identify this locality as a paramo or puna habitat based only on its bird community.

Twenty-three species of the grassland and tola habitats of Tupala were in the list of Vuilleumier \& Simberloff (1980), 20 of them were exclusive of puna sites and only three species, Cinclodes fuscus, Muscisaxicola alpina and Zonotrichia capensis, were present in paramo and puna sites. Species exclusive of paramo sites were not found. 
Our analysis suggests that wet puna shares with the paramo a higher similarity of bird and mammals communities than whatever to do with dry puna. Although there is some ambiguity in the floristic boundaries among Andean highland habitats, it is clear that there is not uniformity in the assemblages of mammal and bird communities. Considering that the distinction has an effect on species with large geographical distribution ranges, ecological more than historical factors, seems to be determinants of this difference.

\section{Acknowledgments}

We are thankful to Irma Francke for providing access to the bird collection of the MUSM, and Dora Susanibar for her assistance with the specimens. We are also thankful to Benjamin Valles, Ely Velázquez and Ronald Garrido, guard parks in the Manu National Park, for giving us logistic facilities during our fieldwork in Acjanaco. We are sincerely grateful to Hermógenes Aduviri and Ubduvilia Mamani for opening their home to us, and the Tupala community for their hospitality. We are very grateful to Kenneth Young and Sergio Solari for their comments and suggestions on a first draft of this article. We thank the Instituto Nacional de Recursos Naturales (INRENA), in Lima and Cusco, for providing us the permits to conduct our fieldwork. This study was supported by a grant from the Concejo Nacional de Ciencia y Tecnología (CONCYTEC), Lima, Perú.

\section{Literature cited}

Anderson S. 1997. Mammals of Bolivia, taxonomy and distribution. Bull. Amer. Mus. Nat. His. 231: 1-652.

Cano A. 1994. Sinopsis de la flora fanerogámica altoandina del Parque Nacional del Manu, Cusco. Tesis de Magister en Botánica Tropical. Universidad Nacional Mayor de San Marcos, Lima.

Cano A., Young K.R., León B. \& Foster R.B. 1995. Composition and Diversity of Flowering Plants in the Upper Montane Forest of Manu National Park, Southern Peru. In S.P. Churchill, H. Balslev, E. Forero \& P.F. Moore (Eds.). Biodiversity and Conservation of Neotropical Montane Forests. Pp. 271-280. New York Botanical Garden, Bronx, U.S.A.

Clements J.F. \& Shany N. 2001. A Field Guide to the Birds of Peru. Ibis Publishing Company. Temecula, California.

Cuatrecasas J. 1957. A sketch of the vegetation of the north-andean province. Proc. $8^{\text {th }}$ Pac. Sci. Congr. 9: 167173.

Fjeldsa J. \& Krabbe N. 1990. Birds of the High Andes. Svendborg, Denmark: Apollo

Koepcke M. 1970. The Birds of the Department of Lima, Peru. Newton Square, PA: Harrowood Books.

MacArthur R.H., Recher H. \& Cody M. 1966. On the relation between habitat selection and species diversity. Amer. Nat. 100: 319-332.

Molina E.G. \& Little A.V. 1981. Geoecology of the Andes: the natural science basis for research planning. Mount. Res. Dev. 1: 115-144.
Myers P., Patton J.L. \& Smith M.F. 1990. A review of the boliviensis group of Akodon (Muridae:Sigmodontinae), with emphasis on Peru and Bolivia. Misc. Publ. Mus. Zool. Univ. Michigan. 177: 1-104.

Pacheco V.R. 2002. Mamíferos del Perú. In G. Ceballos and J.A. Simonetti (Eds.). Diversidad y Conservación de los Mamíferos Neotropicales. Pp. 503-549. CONABIOUNAM. México, DF.

Pacheco V.R. 2003. Phylogenetic analyses of the Thomasomyini (Muroidea: Sigmodontinae) based on morphological data. PhD dissertation, City University of New York, New York.

Pacheco V.R., Patterson B.D., Patton J.L., Emmons L.H., Solari S.A. \& Ascorra C.F. 1993. List of mammals species known to occur in Manu Biosphere Reserve, Peru. Publ. Mus. Hist. Nat. UNMSM. (A) 44: 1-12.

Pacheco V.R. \& Patton J.L. 1995. A new species of the Puna mouse, genus Punomys Osgood, 1943 (Muridae, Sigmodontinae) from the Southeastern Andes of Peru. Z. Säugetierkunde. 60: 85-96.

Patterson B.D, Stotz D.F. \& Solari S.A. 2006. Biological surveys and inventories in Manu. Pp 3-12. In B.D. Patterson, D.F. Stotz and S. Solari (Eds.). Mammals and birds of the Manu Biosphere Reserve, Peru. Fieldiana: Zoology, n.s., $\mathrm{N}^{\circ} 110$.

Patton J.L. \& Smith M.F. 1992. Evolution and systematics of akodontine rodents (Muridae: Sigmodontinae) of Peru, with emphasis on the genus Akodon. Mem. Mus. Hist. Nat. "Javier Prado” Lima. 21: 83-103.

Pearson O.P. \& Ralph C.P. 1978. The diversity and abundance of vertebrates along an altitudinal gradient in Peru. Mem. Mus. Hist. Nat. “Javier Prado” Lima. 18: 197.

Plan Maestro del Parque Nacional del Manu. 2004. Instituto Nacional de Recursos Naturales (INRENA), Projecto Aprovechamiento y Manejo Sostenible de la Reserva de Biosfera y Parque Nacional del Manu (Pro-Manu).

Reig O. 1986. Diversity patterns and differentiation of high Andean rodents. In F. Vuilleumier and M. Monasterio (Eds.). High altitude tropical biogeography. Pp. 404439. Oxford University Press, New York, U.S.A.

Solari S.A. 1997. Relaciones tróficas en una comunidad de roedores altoandinos en el Parque Nacional Manu. Tesis Licenciatura en Biología. Universidad Nacional Mayor de San Marcos.

Solari S.A., Vivar E., Velazco P. \& Rodriguez J.J. 2001. Small mammal diversity from several montane forest localities (1300-2800 m) on the eastern slope of the Peruvian Andes. Biological and Social Assesments of Cordillera Vilcabamba, RAP 12. Conservation International.

Solari S.A., Pacheco V.R., Luna L., Velazco P. \& Patterson B. 2006. Mammals of the Manu Biosphere Reserve. In B.D. Patterson, D.F. Stotz and S. Solari, eds., Mammals and birds of the Manu Biosphere Reserve, Peru. Pp. 1323. Fieldiana: Zoology, n.s., $N^{\circ} 110$.

Spotorno A.E., Valladares J.P., Marín J.C. \& Zeballos H. 2004. Molecular diversity among domestic guinea-pigs (Cavia porcellus) and their close phylogenetic relationship with the Andean wild species Cavia tschudii. Rev. Chil. Hist. Nat. 77: 243-250.

Tossi J.A. 1960. Zonas de vida natural en el Perú. Instituto Interamericano de Ciencias Agrícolas de la OEA Zona Andina. Boletín Técnico. 5: 271. 
Diciembre 2007

Troll C.C. 1959. Die tropischen gebirge, Bonn. Geogr. Abh. 25: $1-93$.

Troll C.C. 1968. The cordilleras of the Tropical Americas: aspects of climatic, phytogeographical and agrarian ecology. In C. Troll (Ed.) Geo-ecology of the mountainous regions of the tropical Americas. Pp. 1556. Ferd. Dümmler Verlag. Bonn, Germany.

Vuilleumier F. 1979. Comparación y evolución de las comunidades de aves de páramo y puna. In M.L. Salgado-Labouriau (Ed.). El medio ambiente páramo. Pp. 181-205. Edición del Centro de Estudios Avanazados, IVIC, Caracas, Venezuela.

Vuilleumier F. \& Simberloff D. 1980. Ecology versus history as determinants of patchy and insular distributions in high Andean birds. In M.K. Hecht, W.C. Steere (Eds.) Evolutionary Biology. 12: 235-379. Plenum Publishing Corporation, New York, USA.
Walker B., Slotz D.F., Pequeño T. \& Fitzpatrick J.W. 2006. Birds of the Manu Biosphere Reserve. Pp. 23-49. In B.D Patterson, D.F. Stotz and S.A Solari (Eds.) Mammals and birds of the Manu Biosphere Reserve, Peru. Fieldiana: Zoology, n.s., $\mathrm{N}^{\circ} 110$.

Weberbauer, A. 1945. El Mundo Vegetal de los Andes Peruanos. Ministerio de Agricultura, Lima.

Young K.R. \& Cano A. 1994. Aporte Florístico de la Puna del Parque Nacional del Manu, Peru. Bol. Lima. 91-96: 381-393.

Young K.R., León B., Cano A., \& Herrera-Macbryde O. 1997. Peruvian Puna. Peru. In S. D. Davis, V. H. Heywood, O. Herrera-MacBryde, J. Villa-Lobos and A. C. Hamilton. (Eds.) Centres of Plant Diversity. A Guide and Strategy for their Conservation. Pp. 470-476. The Americas Vol 3. The World Wide Fund For Nature and IUCN- The World Conservation Union.

\footnotetext{
${ }^{1}$ Unidad de Biología Integrativa, Departamento de Ciencias Biológicas y Fisiológicas, Facultad de Ciencias y Filosofía, Universidad Peruana Cayetano Heredia, Av. Honorio Delgado \# 430, Urbanización Ingeniería, San Martín de Porres, Lima-Perú. Correo electrónico: oramirez@upch.edu.pe / mmarana@upch.edu.pe / enriquealonso3@yahoo.com

${ }^{2}$ Laboratorio de Floristica, Departamento de Dicotiledóneas, Museo de Historia Natural, Universidad Nacional Mayor de San Marcos, Av. Arenales \# 1256, Jesús Maria, Lima- Perú, Correo electrónico: angelmramirezo@yahoo.de / acanoe@unmsm.edu.pe
} 